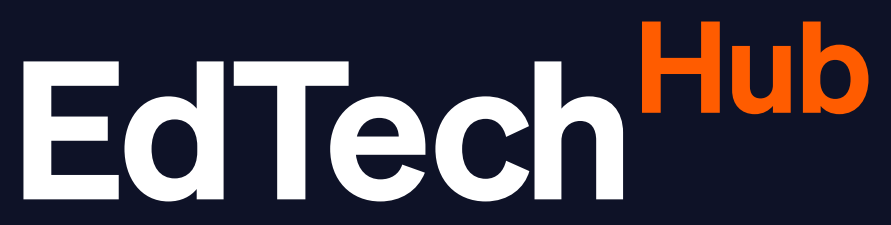

Clear evidence, better decisions, more learning.

\title{
Why the World Needs a Curriculum Alignment Hub
}

Date October 2020

Author Shivi Chandra

DOI $\quad$ 10.53832/edtechhub.0046

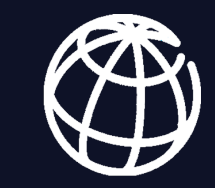

THE WORLD BANK

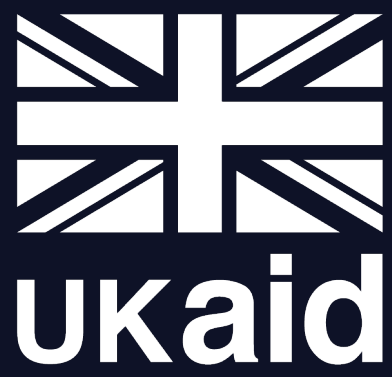




\section{About this document}

Recommended citation

\section{Licence}

\section{Contributors}

Reviewers

Notes
Chandra, S. (2020). Why the World Needs a Curriculum Alignment Hub [Working Paper]. Learning Equality. https://doi.org/10.53832/edtechhub.0046 https://docs.edtechhub.org/lib/2RMKAHXF. Available under Creative Commons Attribution 4.0 International.

Creative Commons Attribution 4.0 International https://creativecommons.org/licenses/by/4.0/ You are free to share (copy and redistribute the material in any medium or format) and adapt (remix, transform, and build upon the material) for any purpose, even commercially. You must give appropriate credit, provide a link to the license, and indicate if changes were made. You may do so in any reasonable manner, but not in any way that suggests the licensor endorses you or your use.

Lauren Lichtman, Jamie Alexandre

Taskeen Adam, Björn Haßler, Abeba Taddese

EdTech Hub is supported by UK aid and the World Bank; however, the views expressed do not necessarily reflect the views of the UK government or the World Bank. 


\section{Contents}

1. Summary 2

2. Background $\quad 4$

2.1. Curricular alignment 4

2.2. Learning Equality's alignment projects $\quad 7$

$\begin{array}{ll}\text { 3. Specific needs } & 8\end{array}$

3.1. Challenges of existing approaches 8

4. Proposed Hub Components 12

4.1. Necessary functions 12

4.2. Intended users and uses $\quad 14$ 


\section{Summary}

This concept note provides an overview of a proposed centralized, dynamic curriculum alignment hub which could support alignment efforts across a larger ecosystem. It poses the need for a hub to facilitate communication between stakeholders who would benefit from aligned materials, and aid in recruitment of and outreach to those who could facilitate it.

This proposed centralized, curriculum alignment hub would have four components:

1. A dynamically updated tracker of existing alignment efforts, sorted by curriculum and content source.

2. An approved, publicly viewable database of professionals qualified to align materials, with CVs and relevant background who can support specialized aspects of curricular alignment work.

3. A discussion and announcement area for funding and sponsorship drives for alignment efforts.

4. A diverse kit of training materials featuring best practices for alignment efforts, downloadable and interoperable templates for sharing, and other onboarding tools.

This concept note is intended for those who work on and may be interested in these issues; this could include educators, platform creators, content providers, funders, and others. The aim is for these interested parties to provide feedback and input on determining a pathway forward. The note includes a high-level discussion of background and key needs surrounding curriculum alignment, a brief discussion of the actors requiring coordination and the types of coordination required, and a detailed specification of potential components needed to develop such a hub.

This concept note is informed by feedback from Learning Equality's existing relationships with grassroots organizations, curriculum bodies, and funders looking to align content, as well as discussions during a design sprint investigating curriculum alignment automation in March 2019 and ongoing discussion related to Digital Public Goods led by Norad. The proposed hub and efforts around it, including discussions of this concept note, are intended to be collaborative and incorporate input from others interested in this community, in order to keep on envisioning together how best to create public goods to make this work easier and more shareable for all. 


\section{Background}

\subsection{Curricular alignment}

Curricular alignment here refers to the process of categorizing diverse digital materials (from a variety of sources and organized based on the logic of their creators) according to their applicability to curricular objectives within a given country curriculum. The process is especially important for learning management systems, platforms, and repositories that rely on using digital materials from different sources to fulfill needs formerly met by a textbook a single source, created by one publisher to the specifications of the official curriculum.

Most collections of digital resources, particularly those created outside a designated country or classroom context, are non-aligned by default. Alignment makes educational content libraries usable by teachers and boosts their performance on most usability metrics of digital content, and is the key preparation step needed to ensure that digital materials are as easy to use as textbooks. In the area of OER research and adoption, many researchers have discovered that alignment is not only key to enhancing the discoverability of resources, but a critical component in their vetting, enabling reviewers to ensure that the unfamiliar library is actually covering all the same material as the existing textbook or other mandated resource.

Around the world, educators might give feedback or speak about the need for curricular alignment of content, without explicitly naming it as such. Where digital learning resources are not aligned, educators could describe challenges related to assessing relevance, communicating curriculum compliance, discovering the right resources, planning lessons, and assessing knowledge. Alignment addresses many of these concerns by matching the structure, vocabulary, navigation, and assessment mechanism of diverse materials to the ways in which a curriculum encourages educators to frame them, and hence saves educators' time in drawing these equivalences themselves. 
Table 1. Characteristics of aligned and non-aligned collections of digital content

\begin{tabular}{|c|c|c|}
\hline & $\begin{array}{l}\text { An aligned collection of digital } \\
\text { content }\end{array}$ & $\begin{array}{l}\text { A non-aligned collection of } \\
\text { digital content: }\end{array}$ \\
\hline $\begin{array}{l}\text { In determining } \\
\text { relevance: }\end{array}$ & $\begin{array}{l}\text { Is tagged or organized into folders } \\
\text { corresponding to curricular } \\
\text { objectives, so that teachers know } \\
\text { exactly which objective the } \\
\text { material is relevant to. }\end{array}$ & $\begin{array}{l}\text { Is organized according to a } \\
\text { scheme that has nothing to do } \\
\text { with the target curriculum, so that } \\
\text { teachers have to look at every } \\
\text { piece of material to determine } \\
\text { whether it is relevant. }\end{array}$ \\
\hline $\begin{array}{l}\text { In ensuring } \\
\text { curriculum } \\
\text { compliance: }\end{array}$ & $\begin{array}{l}\text { Uses vocabulary (in content titles, } \\
\text { tags, folder names, etc.) which } \\
\text { corresponds exactly to the } \\
\text { vocabulary of the target } \\
\text { curriculum, so that compliance is } \\
\text { easy to determine. }\end{array}$ & $\begin{array}{l}\text { Uses vocabulary and terminology } \\
\text { (in content titles, tags, folder } \\
\text { names, etc.) which may be } \\
\text { unfamiliar to users of the target } \\
\text { curriculum. }\end{array}$ \\
\hline $\begin{array}{l}\text { In discovering } \\
\text { resources: }\end{array}$ & $\begin{array}{l}\text { Through its navigational structure, } \\
\text { sequenced the way that the target } \\
\text { curriculum is structured, so that } \\
\text { teachers can click on folders and } \\
\text { find material with knowledge of } \\
\text { what prerequisites have already } \\
\text { been taught. }\end{array}$ & $\begin{array}{l}\text { Has an organizational structure } \\
\text { which may or may not indicate } \\
\text { which materials are covered in } \\
\text { which folder, or before or after } \\
\text { what objective. }\end{array}$ \\
\hline $\begin{array}{l}\text { In planning } \\
\text { lessons: }\end{array}$ & $\begin{array}{l}\text { Is organized so that all content } \\
\text { items correspond in a concrete } \\
\text { way to some curricular objective. }\end{array}$ & $\begin{array}{l}\text { Is organized such that one content } \\
\text { item does not correspond to one } \\
\text { curricular objective, but may } \\
\text { correspond to many or part of one } \\
\text { in such a way that it is not possible } \\
\text { to tell which objective an item } \\
\text { corresponds to. }\end{array}$ \\
\hline $\begin{array}{l}\text { In assessing } \\
\text { knowledge: }\end{array}$ & $\begin{array}{l}\text { Guarantees that completion of } \\
\text { content items, in indicated order, } \\
\text { corresponds to completion of the } \\
\text { official curriculum, equivalent to } \\
\text { utilizing a textbook. }\end{array}$ & $\begin{array}{l}\text { Does not guarantee that } \\
\text { completion of content items in } \\
\text { indicated order corresponds to } \\
\text { completion of the official } \\
\text { curriculum. }\end{array}$ \\
\hline
\end{tabular}

\subsection{Learning Equality's alignment projects}

Learning Equality's Kolibri Content Library is one such digital repository, a collection of Open Educational Resources (OER) that contains several thousand content items (individual units of digital material, such as a text, a video lesson, or an exercise) from approximately 40 different international sources such as Khan Academy, CK-12, NASA, and many more. Sources are 
collections of digital content from organizations with a known educational mandate and a background in producing digital educational content.

Through engaging with its users and stakeholders, the Learning Equality team quickly realized that curriculum alignment was a critical user need in a digital educational library, and began to pursue strategic policy and educator collaborations designed to align and certify parts of the library to national curriculums, in collaboration with the relevant officials where possible, using Learning Equality's Kolibri Studio tool. 


\section{Specific needs}

\subsection{Challenges of existing approaches}

The challenges of existing curricular alignment approaches are numerous, and at an ecosystem level, fall into the approaches shown in the following table.

\section{Table 2. Challenges of existing approaches}

\begin{tabular}{l} 
Approach \\
\hline Alignment of \\
individual \\
content sources \\
by content \\
creators
\end{tabular}

Writers include discussion questions for their material which correspond to a set of learning competencies.

Alignment of
multiple content
sources by
individual or
small groups of
consultants

Subject-matter experts are subsidized to vet and align content.

A review committee of educators assesses a new digital resource or textbook.

The creator of a video series organizes the videos according to their state curriculum.

\section{Challenges}

Most resource creators, working in a limited set of languages and countries, likely will not have capacity to align to multiple country curricula.
Alignment by a content creator likely will not receive official certification by a curricular body due to the barriers to engaging with existing procurement processes for textbooks.

Extremely time-consuming task, requiring retainer for training of educators and subject-matter experts. When unpaid, constitutes a heavy burden of unpaid labor for educators.

Difficult for consultants to standardize on acceptable vetting standards and ideas of alignment.

Crowdsourced alignment via metadata tagging

\author{
Users of a tech platform \\ apply a curricular \\ standard to a resource \\ as a tag.
}

Technologists search for a given word or phrase and apply a curricular standard as a tag.
Incentives to cover a large amount of the curriculum are inconsistent, and some crowdsourced ratings may be inaccurate or inadequately considered, as contributors do not receive training.

Alignment and selected content is not likely to receive official approval due to the inability to assess who exactly made the judgments and what their qualifications were to do so.

Difficult to incentivize, especially for teachers who already spend a great deal of personal time in lesson planning and in assessing new materials.

Though likely the most useful and practical way to align new resources, recommendations are likely to depend

\author{
Teachers add comments \\ referencing a curricular \\ Educators \\ recommending materia \\ to others note which \\ curricular standards it \\ corresponds to.
}

reacher .

$\begin{array}{ll}\text { Crowdsourced } & \text { Educators } \\ \text { alignment via } & \text { recommending material } \\ \text { teacher } & \text { to others note which } \\ \text { recommendation } & \text { curricular standards it } \\ \text { corresponds to. } \\ \\ \\ \text { Teachers add comments } \\ \text { referencing a curricular }\end{array}$


standard to a video or other internet resource. heavily on what any given teacher is able to envision doing or has already done in their particular classroom, and hence may fall short of accounting for all possibilities of content use.

\section{Automated} efforts at alignment
Machine-learning initiatives mine digital content for keywords and match them with curricular standards.

\begin{abstract}
Efforts are mostly still in the early stages of prototyping and testing.

Many teachers and policy bodies may find automated recommendation incomplete, as it presently cannot consider the way that possible pedagogical methods would change the possible role of content sources in a curriculum, and the effects of those changes on the content's relevance.
\end{abstract}

\section{Reliance on} individual educators for alignment via technological platforms

\author{
A teacher sorts digital \\ content into folders on \\ their computer and \\ shares it via USB. \\ A teacher uploads \\ individual resources in \\ their desired structure \\ for class on a platform \\ such as Moodle.
}

\section{Highest burden of labor on teachers, particularly without compensation.}

Difficult to share with other teachers.

Work must be consistently reevaluated as new content is brought into the library.

In scaling, it is evident that all of these approaches to the problem of alignment suffer from challenges of coordination, sharing, lack of standardization, and duplicated work. Entities doing alignment and vetting cannot access training or engage with the necessary bodies who would approve their work, keeping it sequestered from the purposeful ministry approval that enables widespread adoption of digital content and makes traditional, non-digital material, such as the textbook, a more appealing choice. Where alignment and vetting is crowdsourced, the results lack standardization and informed judgment-making based on sets of standards. Specific, localized alignment projects which rely on the expertise of teachers are constrained by the massive amount of time and labor asked of teachers, who as consultants are then involved in the project for only a very brief part of its lifecycle, and cannot update their work or keep track of curricular or content changes. All such alignment efforts are constrained in terms of their mismatch with the speed of content creation: each effort must be replicated when new digital content is added to a library or old content is updated, and unless content creators specifically share this information with those who did the alignment in any given context, there often is no way to track or understand when this happens. 
Due to their decentralized nature and the difficulty of informing others about these efforts, their impact may not propagate across the entire ecosystem, to the point where many stakeholders in the digital content world may not have heard of most of these efforts at all. More importantly, it is evident that no single approach is an overarching best practice to yield aligned digital content, and that it will be necessary for stakeholders to use a mix of approaches, across multiple entities, to ensure widespread curriculum coverage, approval, and updating. 


\section{Proposed components}

In order to address the challenges of these existing approaches in the ecosystem and enable them to scale and build upon one another's work, a curriculum alignment hub is a proposal for a centralized, dynamic hub which serves as a place to coordinate, train, standardize, and share alignment efforts. It would have four components, each of which would address certain common challenges in the approaches detailed above:

1. A dynamically updated tracker of existing alignment efforts by curriculum and content source.

2. An approved, publicly viewable database of consultants with CVs and relevant qualifications who can support specialized aspects of curricular alignment work.

3. A community forum comprising a helpdesk, discussion, and announcement area for funding and sponsorship drives to synthesize alignment efforts.

4. A kit of diverse training materials featuring best practices for alignment efforts, downloadable and interoperable templates for sharing, and other onboarding tools.

\subsection{Necessary functions}

The following chart in Table 3 describes some of the critical functions this hub could fulfill, in order to address the challenges of coordination, sharing, standardization, and duplication. It illustrates a sample workflow of how a set of stakeholders might approach an alignment project, using the hub to fulfill their needs at every stage and leave a record of their work. 
Table 3: Critical functions of a curriculum alignment hub

\begin{tabular}{|c|c|c|c|}
\hline Tracker & Database & Training Center & Discussion Area \\
\hline
\end{tabular}

\section{Scoping}

Identifying needs for an alignment project by viewing existing and previous efforts, connecting with others who have done alignment in a particular content source, curriculum, or language, utilizing the outcomes of this work if openly licensed, and understanding what an aligned curriculum looks like.

1.

An educational nonprofit, wishing to select digital resources and align them to the curriculum in Senegal, searches for resources aligned to the curriculum in the tracker.

2.

They find two content sources in maths which have been aligned, and download curriculum maps for the content from the tracker.
3.

Not understanding how to use the maps, they watch a video about how to read an aligned curriculum map from the training center.
4.

Interested in learning where efforts left off, they connect with the aligners in the discussion area to inquire if there are any life-skills subjects.

\section{5.} Learning that there aren't, they post an announcement in the discussion area asking content creators to recommend their sources for alignment. 


\section{Conceptualizing}

Conceptualizing an alignment project by understanding gaps, identifying discrete outcomes, accounting for needs in vetting or platform selection, and learning about the breadth of content sources available and where to access them. Recruiting \& training any necessary personnel for an alignment project, and providing them with tools to share and collaborate on work.

1.

They note in the tracker that they will be aligning four recommended content sources in French to the Senegalese life-skills curriculum.
2.

Using the database, they recruit

French-speaking educators with experience in life skills or teaching specifically in Senegal.
3.

They download an onboarding exercise from the training center to help finalize terminology and common references across the aligners.

\section{4.}

The consultants download a template for recording their judgments on the individual content items from the training center, and begin their work.
5.

Some of the consultants, disagreeing on their judgment of a particular content item, post in the discussion area for others' opinions.

\section{Sharing}

Sharing outcomes of an alignment project by contextualizing it in terms of larger community work, connecting with others who may wish to support it, and recording outcomes for others' reference in step 7 for the next project.

1.

Consultants record their finished project in the tracker, adding to the coverage of the Senegalese curriculum.

2.

Consultants upload their work and share in the tracker for others' use.
3.

In the discussion area, the nonprofit shares the outcomes and applies for more funding to fund the consultants to create two more content sources.

\section{4.}

In the discussion area, one of the content creators thanks them for the work and updates them that they have another upcoming set of materials they can offer. 


\subsection{Intended users and uses}

Each of the components of the hub provides the opportunity for different stakeholders involved with this process to ask and receive an answer to various questions or difficult processes involved with curriculum alignment projects. Some of these are detailed below.

Table 4. Intended users and uses

\begin{tabular}{|c|c|c|c|c|}
\hline & Tracker & Database & $\begin{array}{l}\text { Training and } \\
\text { resource center }\end{array}$ & Discussion area \\
\hline $\begin{array}{l}\text { Educators } \\
\text { and } \\
\text { consultants }\end{array}$ & $\begin{array}{l}\text { What digital } \\
\text { resources are } \\
\text { aligned to my } \\
\text { curriculum? } \\
\text { Are there any } \\
\text { alignment } \\
\text { projects I would } \\
\text { be able to consult } \\
\text { on for additional } \\
\text { income? } \\
\text { Are there any } \\
\text { resources and } \\
\text { alignment } \\
\text { projects which } \\
\text { have been } \\
\text { approved by our } \\
\text { ministry? }\end{array}$ & $\begin{array}{l}\text { How can I share } \\
\text { my qualifications } \\
\text { and become } \\
\text { involved with } \\
\text { alignment } \\
\text { projects in my } \\
\text { country? } \\
\text { Are there other } \\
\text { educators with } \\
\text { whom I could } \\
\text { collaborate to } \\
\text { split the work to } \\
\text { align a set of } \\
\text { resources for our } \\
\text { upcoming year? }\end{array}$ & $\begin{array}{l}\text { How should I } \\
\text { record my } \\
\text { decisions about } \\
\text { curriculum } \\
\text { alignment? } \\
\text { How can I save } \\
\text { time in } \\
\text { evaluating large } \\
\text { amounts of } \\
\text { content? }\end{array}$ & $\begin{array}{l}\text { I'm not sure } \\
\text { whether this } \\
\text { material is } \\
\text { aligned or not. } \\
\text { What should I } \\
\text { do? } \\
\text { Where can I } \\
\text { submit a request } \\
\text { for a curriculum } \\
\text { aligned in my } \\
\text { language or to } \\
\text { my curriculum? }\end{array}$ \\
\hline Nonprofits & $\begin{array}{l}\text { If we choose to } \\
\text { run a project } \\
\text { using digital } \\
\text { resources, in } \\
\text { which countries } \\
\text { does an aligned } \\
\text { digital curriculum } \\
\text { exist? } \\
\text { What is the } \\
\text { greatest content } \\
\text { alignment need } \\
\text { in our country of } \\
\text { implementation? }\end{array}$ & $\begin{array}{l}\text { Who could we } \\
\text { hire to help us } \\
\text { complete an } \\
\text { alignment } \\
\text { project or assess } \\
\text { the quality of } \\
\text { resources we } \\
\text { were planning to } \\
\text { use? }\end{array}$ & $\begin{array}{l}\text { How can we } \\
\text { onboard our staff } \\
\text { into working with } \\
\text { digital content? }\end{array}$ & $\begin{array}{l}\text { Is anyone else } \\
\text { working in our } \\
\text { country of } \\
\text { implementation } \\
\text { who we can } \\
\text { connect with? }\end{array}$ \\
\hline $\begin{array}{l}\text { Content } \\
\text { creators }\end{array}$ & $\begin{array}{l}\text { Where are our } \\
\text { materials being } \\
\text { used? } \\
\text { Is there anyone } \\
\text { conducting a } \\
\text { project who }\end{array}$ & $\begin{array}{l}\text { Who could help } \\
\text { us align or } \\
\text { internationalize } \\
\text { our materials? }\end{array}$ & $\begin{array}{l}\text { What might } \\
\text { international } \\
\text { audiences look } \\
\text { for in working } \\
\text { with our } \\
\text { materials? }\end{array}$ & $\begin{array}{l}\text { Where can we } \\
\text { share that we } \\
\text { have updated our } \\
\text { materials? } \\
\text { Can we tell } \\
\text { someone }\end{array}$ \\
\hline
\end{tabular}




\begin{tabular}{|c|c|c|c|c|}
\hline & $\begin{array}{l}\text { should know } \\
\text { about our } \\
\text { materials? }\end{array}$ & & & $\begin{array}{l}\text { working on a } \\
\text { relevant project } \\
\text { about our work? }\end{array}$ \\
\hline Ministries & $\begin{array}{l}\text { What are existing } \\
\text { resources aligned } \\
\text { with in our } \\
\text { country? }\end{array}$ & $\begin{array}{l}\text { Who could be } \\
\text { involved in a } \\
\text { curriculum } \\
\text { review process to } \\
\text { review new } \\
\text { standards? }\end{array}$ & $\begin{array}{l}\text { How can we } \\
\text { onboard our staff } \\
\text { into working with } \\
\text { digital content? }\end{array}$ & $\begin{array}{l}\text { Is anyone doing } \\
\text { this work that we } \\
\text { should fund to } \\
\text { complete it to } \\
\text { meet our } \\
\text { specifications? }\end{array}$ \\
\hline $\begin{array}{l}\text { Technology } \\
\text { and } \\
\text { platform } \\
\text { creators }\end{array}$ & $\begin{array}{l}\text { Which curricular } \\
\text { resources and } \\
\text { structures could } \\
\text { we import? } \\
\text { Where is the need } \\
\text { to use our } \\
\text { projects? }\end{array}$ & $\begin{array}{l}\text { Is there anyone } \\
\text { we could } \\
\text { collaborate with } \\
\text { to assist with } \\
\text { content sourcing } \\
\text { in a language we } \\
\text { don't speak? }\end{array}$ & $\begin{array}{l}\text { What are the } \\
\text { workflows } \\
\text { involved with } \\
\text { curriculum } \\
\text { alignment? } \\
\text { Where can we } \\
\text { upload } \\
\text { something } \\
\text { standardized in } \\
\text { our format to } \\
\text { record } \\
\text { outcomes? }\end{array}$ & $\begin{array}{l}\text { Is anyone doing } \\
\text { this work that we } \\
\text { should fund to } \\
\text { complete it to } \\
\text { meet our } \\
\text { specifications? }\end{array}$ \\
\hline
\end{tabular}

